\title{
THE INFLUENCE OF TECHNOLOGY READINESS ON BEHAVIORAL INTENTION (CASE STUDY OF ONLINE TRANSPORTATION IN INDONESIA AND THAILAND)
}

\author{
Ribka Cynthia F Munthe*), Jono M Munandar ${ }^{* *}$, and Muhammad Syamsun ${ }^{* *}$ \\ *) Graduate School, IPB University \\ Jl. Raya Pajajaran, Bogor 16151 \\ **) Departement of Management, Faculty of Economics and Management, IPB University \\ Jl. Agatis, Campus IPB Dramaga Bogor 16680
}

\begin{abstract}
One of the popular technology-based services is online transportation. The company provides transportation services that can be accessed through an application on a smartphone. Therefore, the technology readiness of consumers needs to estimate the perception and behavior of the consumer. This research compared online transportation in Indonesia and Thailand by identifying the characteristics and technology readiness of online transportation consumers and the influence of technology readiness towards behavioral intention. This research was conducted in Indonesia and Thailand by a survey on 500 university students who were the online transportation consumers. The study used descriptive analysis and Partial Least Squares (PLS) analysis. Data processing used Mirosoft Excel 2010 software and SMART PLS. The results showed that consumer's perception in Indonesia and Thailand was no different. In hypothesis test found that two accepted hypotheses, H1: optimism affected behavioral intention, and H5: favorableness affected behavioral intention.
\end{abstract}

Keywords: behavioral intention, favorableness, online transportation, SEM PLS, technolgy readiness

\begin{abstract}
Abstrak: Salah satu layanan berbasis teknologi yang populer adalah transportasi online. Perusahaan menyediakan layanan transportasi yang dapat diakses melalui aplikasi pada smartphone. Oleh karena itu, kesiapan teknologi konsumen perlu dilihat untuk memperkirakan persepsi dan perilaku konsumen. Penelitian ini akan menganalisis perbandingan transportasi online di Indonesia dan Thailand, di mana tujuannya adalah untuk mengidentifikasi karakteristik dan kesiapan teknologi transportasi online konsumen di Indonesia dan Thailand dan untuk menganalisis pengaruh kesiapan teknologi terhadap niat perilaku pada konsumen transportasi online. Penelitian ini dilakukan di Indonesia dan Thailand dengan menggunakan kuesioner kepada 500 mahasiswa yang merupakan konsumen transportasi online. Metode yang adalah analisis deskriptif dan analisis Partial Least Squares (PLS). Pemrosesan data menggunakan bantuan perangkat lunak Mirosoft Excel 2010 dan SMART PLS. Hasil penelitian menunjukkan bahwa persepsi konsumen di Indonesia dan Thailand memiliki hasil yang tidak jauh berbeda. Dalam pengujian hipotesis ditemukan dua hipotesis yang diterima, H1 yang menyatakan bahwa optimisme berpengaruh pada niat perilaku dan H5 yang menyatakan bahwa kesukaan berpengaruh pada niat perilaku.
\end{abstract}

Kata kunci: behavioral intention, favorableness, online transportation, SEM PLS, technolgy readiness

${ }^{1}$ Corresponding author:

Email: afifbobby@gmail.com 


\section{INTRODUCTION}

The development of internet-based technology in today's digital era provides convenience for consumers to get products and services they want. Technology became one of the things that are inseparable from humans. Its development then has an impact on the increasing number of internet users. According to the survey of Indonesian Internet Service Providers Association (APJII) in 2018, the number of internet users in Indonesia reached 143.26 million people, more than half of Indonesia's population that currently reach 262 million people. The development of technology on a country is supported by technological readiness of its people, or better known as the technology readines. As Parasuraman and Colby (2014) argues, technology readiness refers to people's propensity to embrace and use new technologies for accomplishing goals in home life and at work. There are four dimensions on technology readiness, namely, optimism (a positive view of technology and a belief that it offers people increased control, flexibility and efficiency in their lives), innovativeness (a tendency to be a technology pioneer and thought leader), discomfort (a perceived lack of control over technology and a feeling of being overwhelmed by it) and insecurity (distruct of technology and skepticism about its ability to work properly). Based on Table 1, Indonesia ranked 67 in the world and the 6th position in South-East Asia for tehnology readiness.

The importance of the technology readiness is due to the increasing number of digital techology-based services companies that have emerged to replace conventional companies. Consumer convenience in using the internet and meet their needs simply by using a smartphones makes digital techology-based services companies very well known and get high profits. The effect of technological development is the emergence of the service providers that provide service online (Lin et al. 2006), and that is why, one of the popular technology based service nowadays is online transportation. It has several unique differences compared to other online services because it has distinct services process, involves inseperable physical services (drivers and vehicle) and the user's tendency to use the services repeatedly (Silalahi et al. 2017). In Indonesia, online transportation that has a large market are Go-Jek and Grab, which made competition in this industry even tighter (Santoso and Nelloh, 2017; Aziah and Adawia 2018). These companies become the consumer favorite choice in meeting their transportation needs besides taxis, buses and other public transportations, especially in the cities in Indonesia which tend to experience congestion before and after office hours (Nurhidayah and Alkarim, 2017). In offering transportation services, Go-Jek and Grab also offers food delivery, courier, clean up, delivery groceries, truck service, massage service, woman skin care service, ticket booking service and busway monitoring service.

People tend to use online transportation to avoid congestion, which is a problem that often occurs in every country (Speranza, 2018), especially Indonesia. Therefore, companies of online transportation, should not be focused on the product only, but also market, competitors, users, suppliers to be identified real opportunities for innovation (Moroni et al. 2015). Some customers feel uncomfortable when confronted with self-service technology, because of the need for an understanding about the technology system used (Parasuraman, 2000), so it is important to identify this in determining the company's strategies. In making a decision to make an online purchase, consumers will make considerations such as searching for information about a product, considering other product alternatives, until finally deciding to make a purchase (Indrayana et al. 2016).

Therefore, by understanding the differences in people's technological readiness in Indonesia and Thailand, the companies need to look at existing market opportunities. The differences in the characteristic of Indonesia and Thailand communities can also be one of the things that affect their technology readiness to behavioral intention on online transportation use. Therefore, the objective of this research are: 1) To differentiate the consumer's characteristics of online transportation in Indonesia and Thailand; 2) To analyze technology readiness on the consumer online transportation in Indonesia and Thailand; 3) To analyze the influence of technology readiness to the behavioral intention on consumer online transportation in Indonesia and Thailand. 
Table 1. Technology readiness ranking 2018-2022

\begin{tabular}{lcc}
\hline Country & Score & Ranking \\
\hline Singapore & 9.7 & 1 \\
Malaysia & 7.4 & 27 \\
Thailand & 5.7 & 49 \\
Philipina & 5.5 & 55 \\
Vietnam & 4.6 & 65 \\
Indonesia & 4.3 & 67 \\
\hline Source: The Economist Intelligence Unit(2018)
\end{tabular}

\section{METHODS}

This research was conducted in Indonesia and Thailand. Location selection is based on the background of the study. Primary and secondary data collection was conducted in February to April 2019. Types and sources of the data for this research are primary and secondary data. Primary data were taken through interview using questionnaire instrument to 250 students of Bogor Agricultural University and 250 students of Kasetsart University. Secondary data were taken from journals, books, previous research and internet.

The sampling method used in this study is classified as a non probability method. The non probability sampling technique used is convenience sampling with the total sample of 500 people consisting of 250 respondents from each country. The data analysis used in this study is quantitative and qualitative analysis. The analytical tool used is descriptive analysis and Partial Least Squares (PLS) analysis, to refine the test done in advance of the validity and reliability test. Data processing is done using Microsoft Excel 2010, SPSS and SMART PLS 3.

There are nine hypothesis in this study. Nugroho and Fajar (2017) stated that optimism and innovativeness have an effect on behavioral intention. Therefore, we infer that optimism and innovativeness will influence behavioral intention.

H1: Optimism affects behavioral intention

$\mathrm{H} 2$ : Innovativeness affects behavioral intention

Lin and Hsieh (2007) stated that technology readiness has an effect on behavioral intention. So, we hypothesize that:

H3: Discomfort affects behavioral intention

H4: Insecurity affects behavioral intention
In addition, a moderating effect will be examinend to show the interaction between favorableness variables and independent variables in influencing the dependent variable (Zeithaml et al. 1996), i.e.

H5 : Favorableness affects behavioral intention

H6 : Favorableness moderates the relationship between optimism and behavioral intention

H7 : Favorableness moderates the relationship between innovativeness and behavioral intention

H8 : Favorableness moderates the relationship between discomfort and behavioral intention

H9 : Favorableness moderates the relationship between insecurity and behavioral intention

As illustrated in Figure 1, Online transportation is one example of companies which implement internet-based technology in delivering services. The development of this technology should also consider the technology readiness of its customers. According to The Economist Intelligence Unit (2018), Indonesia's position on technology readiness ranked sixth in Southeast Asia and Thailand were on the third place. However, even though Indonesia's position is lower than Thailand, the number of online transportation in Indonesia is quite high, which means many people knew and used online transportation. Therefore, this study aims to analyze the influence of technology readiness on behavioral intention.

\section{RESULTS}

\section{Characteristics of Respondents}

The respondents used in this study were those who had used online transportation. Based on the results of data collection obtained through the distribution of questionnaires to 500 research respondents, it can be concluded that the respondents were dominated by female (as much as 80 percent) with the majority of respondents in the age range of $16-25$ years. This is because the respondents are also dominated by students who are in the bachelor education level. This also caused the marriage status of the respondents to be dominated by singles. When viewed from the average total income, the majority of respondents had income in the range of Rp1,000,001 to Rp2,500,000 for Indonesia and less than 10,000 Baht $(<\mathrm{Rp} 4,500,000)$ for Thailand. Meanwhile, for the average total expenditure, it is dominated by a 
range of Rp500,001 to Rp250,000 for Indonesia and 5,000-10,000 Baht (Rp250,000 - Rp4,500,000) for Thailand.

\section{The Influence of Technology Readiness to Behavioral Intention (Using Structural Equation Model (SEM) Analysis)}

Structural Equation Model (SEM) is a multivariate analysis technique that is commonly used to construct and test statistical models that are usually shaped as a cause and effect model and in development are more powerful because they consider interaction modeling, nonlinearity, correlated independents, correlated error terms, measurementerrors, latent multipleindependents, each of which is measured using many indicators, and one or two latent dependent variables, each of which is also measured by several indicators (Sarwono, 2013). In this study, the SEM analysis used was SEM PLS with the help of SMART PLS 3 software.

\section{Model Estimation}

There are three stages in analyzing PLS, namely outer model analysis, inner model analysis and hypothesis testing. In the initial stage of the analysis, the outer model analysis will be carried out by looking at three indicators, namely convergent validity, discriminant validity and composite reliability. Next, an inner model analysis was performed using R-square and path coefficients for interconstructive significance tests in structural models. R-square is used to measure the level of variation in changes in the independent variable on the dependent variable. The path coefficient values indicate the level of significance in testing hypotheses performed by looking at the value of the T-statistic. The hypothesis is accepted when the T-statistic $>1.96$ at alpha 5 percent (Abdillah and Jogiyanto, 2015; Ghozali, 2014).

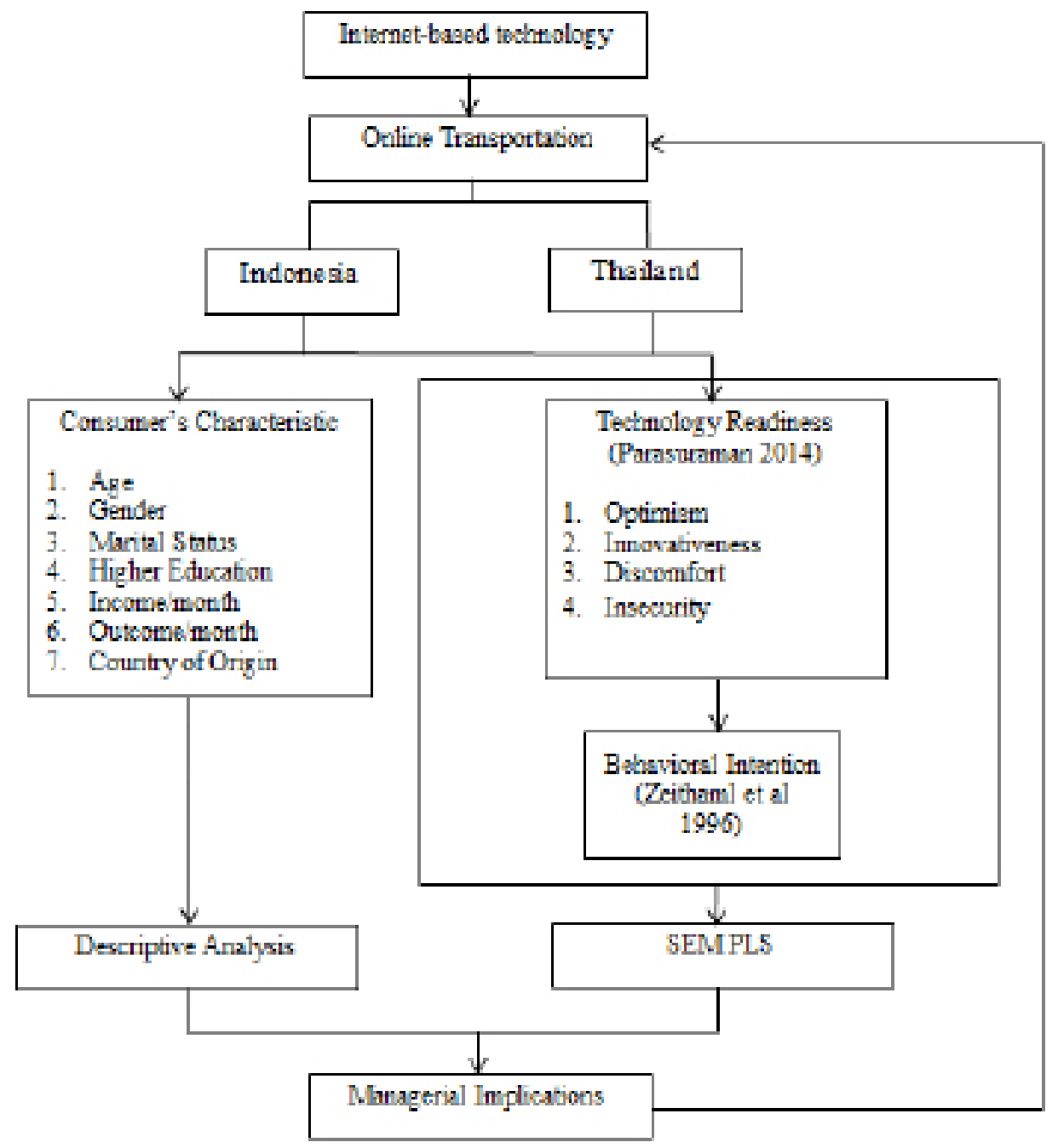

Figure 1. Research framework 


\section{Outer Model Analysis}

This analysis is conducted to see the relationship between latent variables and their indicators. First, to see convergent validity, the coefficients of each indicator will be seen. Indicators that have a loading factor below 0.7 are considered inappropriate and must be removed from the model. However, according to Abdillah and Jogiyanto (2015), researchers should not delete indicators that have outer loading $0.5-0.7$, as long as the AVE score and communality of the variable are more than 0.5 . The results of initial and final convergent validity can be seen in Table 2 .

Table 2 shows that of all indicators, there are still indicators whose coefficient values do not meet the requirements, therefore improvements are made by removing the indicator. There are a number of indicators removed from Indonesia's initial models, namely OPT4, OPT7, OPT8, OPT9, OPT10 and OPT12 from optimism, DIS6, DIS8, DIS9, DIS10, DIS11, DIS12 and DIS13 from discomfort, INS1, INS2, INS3, INS4, INS5, INS6, INS7, INS8, INS10 and INS11 from insecurity and $\mathrm{B} 5$ from the behavioral intention variable. This shows that, these indicators cannot reflect their respective variables. For the innovativeness variable, all indicators can reflect the variables well. As a result, all indicators, there are only twenty-seven indicators that meet the standard values. Indonesian respondents indicated that the remaining indicators were indicators that could reflect their respective variables.

Table 2. The result of initial and final convergent validity in Indonesia and Thailand

\begin{tabular}{|c|c|c|c|c|}
\hline \multirow[t]{2}{*}{ Indicator } & \multicolumn{2}{|c|}{ Indonesia } & \multicolumn{2}{|c|}{ Thailand } \\
\hline & Initial & Final & Initial & Final \\
\hline OPT1 & 0.697 & 0.735 & 0.738 & 0.743 \\
\hline OPT2 & 0.695 & 0.782 & 0.677 & 0.683 \\
\hline OPT3 & 0.628 & 0.688 & 0.756 & 0.759 \\
\hline OPT4 & 0.585 & Removed & 0.793 & 0.806 \\
\hline OPT5 & 0.666 & 0.708 & 0.708 & 0.722 \\
\hline OPT6 & 0.719 & 0.747 & 0.773 & 0.776 \\
\hline OPT7 & 0.633 & Removed & 0.723 & 0.733 \\
\hline OPT8 & 0.615 & Removed & 0.519 & Removed \\
\hline ОРТ9 & 0.611 & Removed & 0.710 & 0.695 \\
\hline OPTT10 & 0.663 & Removed & 0.733 & 0.736 \\
\hline OPT11 & 0.685 & 0.707 & 0.703 & 0.702 \\
\hline OPT12 & 0.578 & Removed & 0.535 & 0.530 \\
\hline INN1 & 0.694 & 0.683 & 0.653 & 0.652 \\
\hline INN2 & 0.688 & 0.675 & 0.735 & 0.733 \\
\hline INN3 & 0.676 & 0.667 & 0.735 & 0.734 \\
\hline INN4 & 0.758 & 0.756 & 0.718 & 0.720 \\
\hline INN5 & 0.801 & 0.797 & 0.743 & 0.746 \\
\hline INN6 & 0.667 & 0.678 & 0.693 & 0.694 \\
\hline INN7 & 0.734 & 0.735 & 0.710 & 0.710 \\
\hline INN8 & 0.716 & 0.728 & 0.810 & 0.808 \\
\hline INN9 & 0.688 & 0.693 & 0.699 & 0.700 \\
\hline DIS1 & 0.708 & 0.736 & 0.688 & 0.745 \\
\hline DIS2 & 0.766 & 0.789 & 0.712 & 0.758 \\
\hline DIS3 & 0.700 & 0.687 & 0.672 & 0.724 \\
\hline DIS4 & 0.690 & 0.733 & 0.630 & 0.662 \\
\hline DIS5 & 0.609 & 0.668 & 0.630 & 0.682 \\
\hline
\end{tabular}

\begin{tabular}{|c|c|c|c|c|}
\hline \multirow[t]{2}{*}{ Indicator } & \multicolumn{2}{|c|}{ Indonesia } & \multicolumn{2}{|c|}{ Thailand } \\
\hline & Initial & Final & Initial & Final \\
\hline DIS6 & 0.600 & Removed & 0.689 & 0.711 \\
\hline DIS7 & 0.604 & 0.644 & 0.607 & 0.686 \\
\hline DIS8 & 0.608 & Removed & 0.566 & Removed \\
\hline DIS9 & 0.373 & Removed & 0.617 & Removed \\
\hline DIS10 & 0.431 & Removed & 0.631 & Removed \\
\hline DIS11 & 0.558 & Removed & 0.600 & Removed \\
\hline DIS12 & 0.515 & Removed & 0.486 & Removed \\
\hline DIS13 & 0.405 & Removed & 0.478 & Removed \\
\hline INS1 & 0.611 & Removed & 0.643 & 0.618 \\
\hline INS2 & 0.645 & Removed & 0.720 & 0.726 \\
\hline INS3 & 0.524 & Removed & 0.632 & 0.622 \\
\hline INS4 & 0.372 & Removed & 0.449 & Removed \\
\hline INS5 & 0.489 & Removed & 0.734 & 0.733 \\
\hline INS6 & 0.591 & Removed & 0.797 & 0.799 \\
\hline INS7 & 0.521 & Removed & 0.697 & 0.690 \\
\hline INS8 & 0.625 & Removed & 0.803 & 0.812 \\
\hline INS9 & 0.689 & 1.000 & 0.794 & 0.813 \\
\hline INS10 & 0.578 & Removed & 0.711 & 0.734 \\
\hline INS11 & 0.398 & Removed & 0.730 & 0.744 \\
\hline FAV1 & 1.000 & 1.000 & 1.000 & 1.000 \\
\hline BI1 & 0.770 & 0.762 & 0.826 & 0.843 \\
\hline BI2 & 0.787 & 0.806 & 0.877 & 0.878 \\
\hline $\mathrm{BI} 3$ & 0.532 & 0.526 & 0.724 & 0.708 \\
\hline BI4 & 0.783 & 0.800 & 0.833 & 0.851 \\
\hline BI5 & 0.344 & Removed & 0.491 & Removed \\
\hline
\end{tabular}


Whereas for Thailand, the initial model is the same as Indonesia, has four moderating effects derived from moderating the variable "favorableness". In contrast to Indonesia, the final model from Thailand still has many indicators remaining because only a few indicators do not meet standards, namely OPT8 from optimism variables, INS4 from variables insecurity, BI5 from the behavioral variable and DIS8, DIS9, DIS10, DIS11, DIS12 and DIS13 from variable discomfort. All indicators on the innovativeness variable are able to reflect these variables well, so that there are 42 indicators that have met the requirements. This shows that compared to Indonesia, the indicators removed from the results of the Thai model are far less. More indicators are considered to reflect each variable.

After testing for convergent validity, discriminant validity is then used to analyze whether the indicator can reflect its latent variables by looking at the cross loading score. The value of cross loading construct correlation with the measurement item is expected to be greater than the size of other constructs. In addition, the measurement is continued by comparing the square root of avarage variance extracted (AVE) values of each construct. The model is said to have good discriminant validity value if the AVE square root value in each construct is greater than the correlation value between constructs and other constructs.

To declare the reliability of the model, it will be tested by looking at the composite reliability (CR) and cronbach alpha. If the CR and cronbach's alpha values are greater than 0.7 , the construct is declared reliable. The values of AVE, CR and cronbach's alpha in the Indonesian model can be seen in Table 3 while for the Thai model can be seen in Table 4 .

Based on Table 3 and Table 4 it is found that all the cronbach's alpha, CR and AVE values meet the criteria. Further explanation of the comparison between Indonesia and Thailand models can be seen in Table 5 which explains five criteria, namely composite reliability (CR), cronbach's alpha, reliablity indicators, avarage variance extracted (AVE), discriminant validity of cross loading criteria and discriminant validity of Fornell-Larcker criterion.

Table 3. Test results of the Indonesian cronbach's alpha, CR and AVE model

\begin{tabular}{lccc}
\hline & Cronbach's alpha & CR & AVE \\
\hline Behavioral_Intention & 0.712 & 0.819 & 0.537 \\
Discomfort & 0.808 & 0.859 & 0.506 \\
Favorableness & 1.000 & 1.000 & 1.000 \\
Innovativeness & 0.880 & 0.903 & 0.509 \\
Insecurity & 1.000 & 1.000 & 1.000 \\
ME_DIS & 1.000 & 1.000 & 1.000 \\
ME_INN & 1.000 & 1.000 & 1.000 \\
ME_INS & 1.000 & 1.000 & 1.000 \\
ME_OPT & 1.000 & 1.000 & 1.000 \\
Optimism & 0.825 & 0.871 & 0.531 \\
\hline
\end{tabular}

Table 4. Test results of the Thailand cronbach's alpha, CR and AVE model

\begin{tabular}{lccc}
\hline & Cronbach's alpha & CR & AVE \\
\hline Behavioral_Intention & 0.841 & 0.893 & 0.677 \\
Discomfort & 0.844 & 0.877 & 0.505 \\
Favorableness & 1.000 & 1.000 & 1.000 \\
Innovativeness & 0.889 & 0.908 & 0.523 \\
Insecurity & 0.902 & 0.920 & 0.536 \\
ME_DIS & 1.000 & 1.000 & 1.000 \\
ME_INN & 1.000 & 1.000 & 1.000 \\
ME_INS & 1.000 & 1.000 & 1.000 \\
ME_OPT & 1.000 & 1.000 & 1.000 \\
Optimism & 0.906 & 0.921 & 0.518 \\
\hline
\end{tabular}




\section{Structural Model Evaluation (Inner Model Analysis)}

At this stage, the structural model is evaluated using $\mathrm{R}$-square for the dependent construct and the value of the path or t-value coefficients for each path for the interconstructive significance test in the structural model. The R-square value is used to measure the level of variation in changes in the independent variables on the dependent variable (Abdillah and Jogiyanto, 2015). The $\mathrm{R}$ square values of the final models of Indonesia and Thailand are 0.532 and 0.508 , respectively. This means that for the Indonesian model behavioral intention variability can be explained by variables of optimism, innovativeness, discomfort, insecurity and favorableness as much as 53.20 percent and the remainder explained by other variables outside the study. Whereas in the Thai model of 50.80 percent the variables of optimism, innovativeness, discomfort, insecurity and favorableness are considered to be able to explain behavioral intention variability with the remaining 49.20 percent explained by the variables outside the research.

The value of the path coefficient or inner model shows the level of significance in the T-statistic value in testing the hypothesis. The results are said to have a significant effect if they have a T-statistic value greater than 1.96. This stage is carried out by the bootstrapping method, which the final results can be seen in Figure 2 and Figure 3 for each country.

T-statistic test results and hypotheses can be seen in Table 6 (Indonesia) and Table 7 (Thailand). Based on the table, it is known that the Indonesian and Thai models have the same results, that is, there are only two significant relationships. Favorableness variable are known to have a positive and significant influence on behavioral intention (H5 is accepted). Although it has a significant relationship but in this study favorableness which acts as a moderator variable does not provide a significant relationship on each independent variable relationship to the dependent variable seen from the T-statistic value in ME_DIS $\rightarrow$ Behavioral_Intention, ME_INN $\rightarrow$ Behavioral_Intention, ME_INS $\rightarrow$ Behavioral_Intention and ME_OPT $\rightarrow$ Behavioral_ Intention which is smaller than 1.96. Therefore, it is concluded that the hypotheses $\mathrm{H} 6, \mathrm{H} 7, \mathrm{H} 8$ and $\mathrm{H} 9$ are rejected. This shows that the variable favorableness does not show interaction with the independent variable (optimism, innovativeness, discomfort and insecurity) in influencing the dependent variable (behavioral intention), therefor the level of favorableness for online transportation is not influential in shaping technological readiness in encouraging increased behavioral intention.

Table 5. Comparison of the results of the measurement model

\begin{tabular}{|c|c|c|c|}
\hline \multirow{2}{*}{ Outer Model Test } & \multirow{2}{*}{ Criterion } & \multicolumn{2}{|c|}{ Result } \\
\hline & & Indonesia & Thailand \\
\hline Composite reliability (CR) & $\begin{array}{l}\text { The value must be greater } \\
\text { than } 0.7\end{array}$ & $\begin{array}{l}\text { All of latent variables have } \\
\text { composite reabilty above } 0.7 \\
\text { (Table } 3 \text { ) }\end{array}$ & $\begin{array}{l}\text { All of latent variables have } \\
\text { composite reabilty above } 0.7 \\
\text { (Table } 4 \text { ) }\end{array}$ \\
\hline Cronbach's alpha & $\begin{array}{l}\text { The value must be greater } \\
\text { than } 0.7\end{array}$ & $\begin{array}{l}\text { All of latent variables have } \\
\text { cronbach's alpha above } 0.7 \\
\text { (Table } 3 \text { ) }\end{array}$ & $\begin{array}{l}\text { All of latent variables have } \\
\text { cronbach's alpha above } 0.7 \\
\text { (Table 4) }\end{array}$ \\
\hline Indicator reliability & $\begin{array}{l}\text { The value of loading factor } \\
\text { is between } 0.5-0.7\end{array}$ & $\begin{array}{l}\text { All of loading factor have } \\
\text { value }>0.5 \text { (Table } 2)\end{array}$ & $\begin{array}{l}\text { All of loading factor have } \\
\text { value }>0.5 \text { (Table } 2)\end{array}$ \\
\hline $\begin{array}{l}\text { Avarage Variance Extracted } \\
\text { (AVE) }\end{array}$ & $\begin{array}{l}\text { The value must be greater } \\
\text { than } 0.5\end{array}$ & $\begin{array}{l}\text { All of latent variables have } \\
\text { AVE value }>0.5 \text { (Table } 3)\end{array}$ & $\begin{array}{l}\text { All of latent variables have } \\
\text { AVE value }>0.5 \text { (Table } 4)\end{array}$ \\
\hline $\begin{array}{l}\text { Discriminant validity of } \\
\text { cross loading criteria }\end{array}$ & $\begin{array}{l}\text { The value of cross load- } \\
\text { ing construct correlation } \\
\text { with measurement items is } \\
\text { greater than the size of other } \\
\text { constructs }\end{array}$ & $\begin{array}{l}\text { All of cross loading have } \\
\text { value greater than the size } \\
\text { of other constructs (have } \\
\text { qualified) }\end{array}$ & $\begin{array}{l}\text { All of cross loading have } \\
\text { value greater than the size } \\
\text { of other constructs (have } \\
\text { qualified) }\end{array}$ \\
\hline $\begin{array}{l}\text { Discriminant validity of } \\
\text { Fornell-Larcker critetion. }\end{array}$ & $\begin{array}{l}\text { The root of the AVE of a } \\
\text { construct must be higher } \\
\text { than the correlation between } \\
\text { the latent variables }\end{array}$ & $\begin{array}{l}\text { All of AVE have root higher } \\
\text { than the correlation between } \\
\text { the latent variables (have } \\
\text { qualified) }\end{array}$ & $\begin{array}{l}\text { All of AVE have root higher } \\
\text { than the correlation between } \\
\text { the latent variables (have } \\
\text { qualified) }\end{array}$ \\
\hline
\end{tabular}




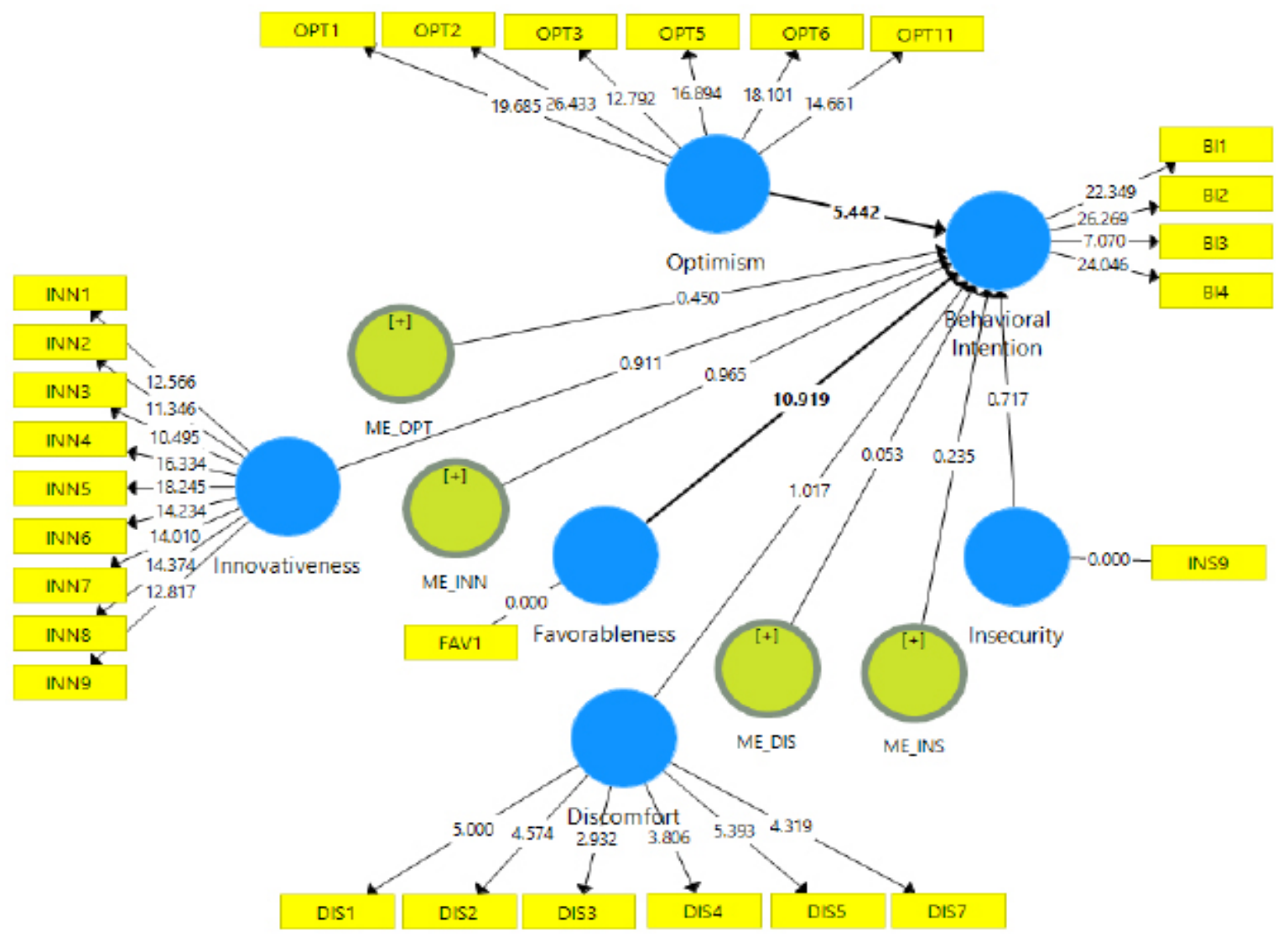

Figure 2. Model and final calculation using bootstraping (Indonesia)

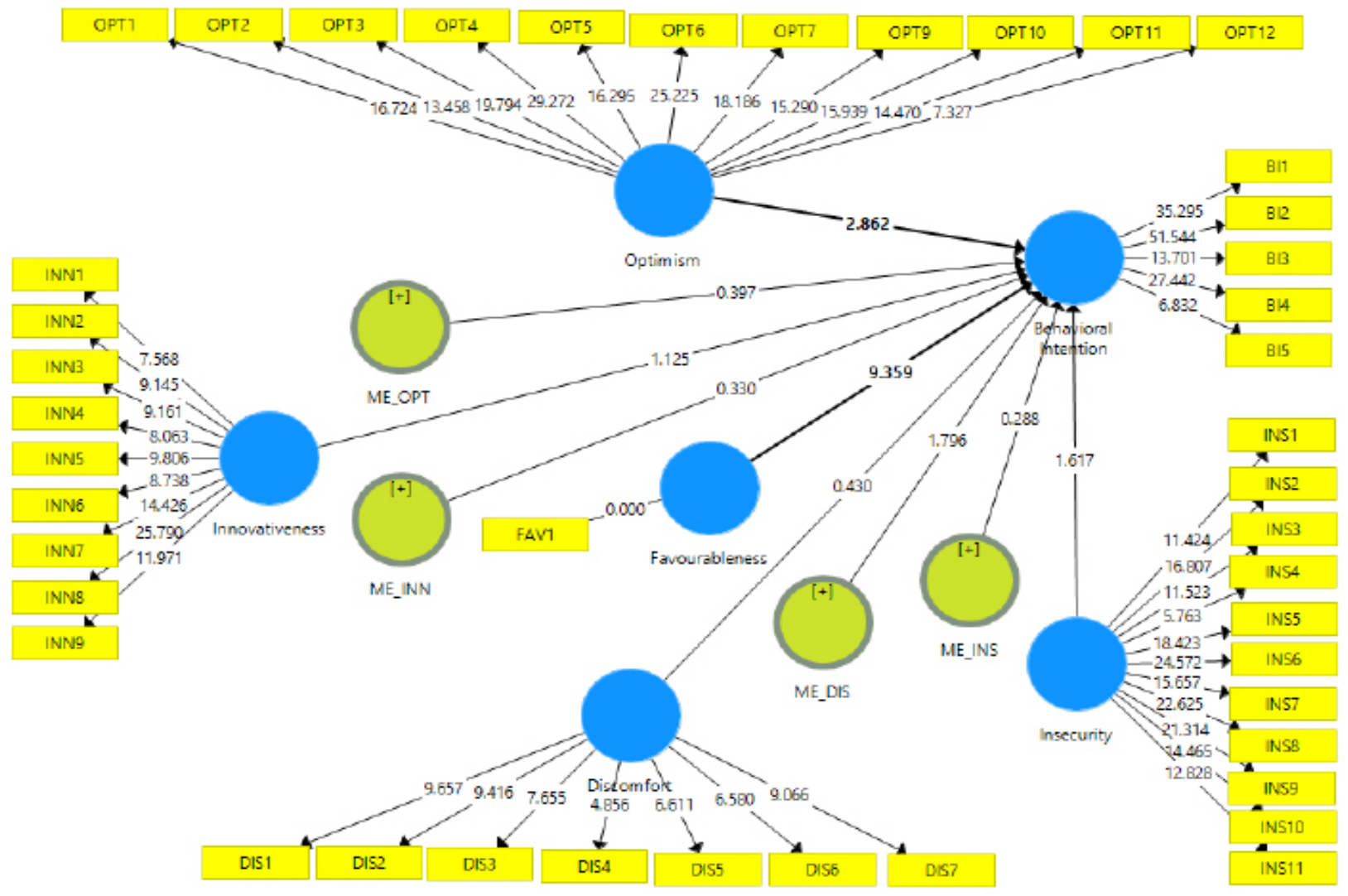

Figure 3. Model and final calculation using bootstraping (Thailand) 
In addition, based on Table 6 and Table 7, it is known that the optimism variable has a positive and significant effect on behavioral intention (H1 accepted). This means that the higher the level of optimism a person has, the higher the behavioral intention towards using online transportation. This is supported by the research of Lin and Hsieh (2007) which states that technology readiness has a positive effect on behavioral intention. Someone who has a positive view and high trust in technology tends to have a high level of loyalty towards him. Therefor it can be concluded that the level of loyalty in Indonesia and Thailand towards online transportation is influenced by the used belief in the technology itself.

However, in this study both in Indonesia and Thailand, the variables of innovativeness, discomfort and insecurity did not have a significant effect on behavioral intention. The tendency of someone to be a pioneer in using technology does not necessarily make him loyal to a technology. Therefore, the innovativeness variable does not have a significant effect on someone's behavioral intention to use online transportation ( $\mathrm{H} 2$ is rejected). This is supported by the research of Septiani et al. (2017), where innovativeness has no effect on behavioral intention, which can be caused by high consumer consumptive but low innovative mind. Another reason is that indicators of innovativeness reflect that one can use or buy the latest available technology, which also relates to the income of that person. The latest technology has a fairly expensive price and if someone is always a pioneer in its use, of course the person has a large enough income to buy it. Whereas in this study, respondents were dominated by students whose income was dominated in the range of Rp1,000,001 to Rp2,500,000 for Indonesia and less than 10,000 Baht for Thailand. That is why innovativeness variables have no influence on behavioral intention in both Indonesia and Thailand. The use of online transportation and consumer loyalty in using it is not influenced by how consumers can buy or use the most recent technology.

Table 6. Indonesia path coefficient results

\begin{tabular}{lcccc}
\hline & Original Sample $(\mathrm{O})$ & T Statistics & P Values & Hypotheses \\
\hline Discomfort $\rightarrow$ Behavioral_Intention & 0.056 & 0.973 & 0.331 & Not Significant \\
Favorableness $\rightarrow$ Behavioral_Intention & 0.554 & 11.245 & 0.000 & Significant \\
Innovativeness $\rightarrow$ Behavioral_Intention & 0.042 & 0.872 & 0.384 & Not Significant \\
Insecurity $\rightarrow$ Behavioral_Intention & 0.038 & 0.738 & 0.461 & Not Significant \\
ME_DIS $\rightarrow$ Behavioral_Intention & 0.003 & 0.051 & 0.960 & Not Significant \\
ME_INN $\rightarrow$ Behavioral_Intention & -0.047 & 1.010 & 0.313 & Not Significant \\
ME_INS $\rightarrow$ Behavioral_Intention & -0.013 & 0.246 & 0.806 & Not Significant \\
ME_OPT $\rightarrow$ Behavioral_Intention & 0.028 & 0.480 & 0.632 & Not Significant \\
Optimism $\rightarrow$ Behavioral_Intention & 0.275 & 5.445 & 0.000 & Significant \\
\hline
\end{tabular}

Table 7. Thailand path coefficient results

\begin{tabular}{lcccc}
\hline & Original Sample $(\mathrm{O})$ & T Statistics & P Values & Hypotheses \\
\hline Discomfort $\rightarrow$ Behavioral_Intention & -0.025 & 0.430 & 0.667 & Not Significant \\
Favorableness $\rightarrow$ Behavioral_Intention & 0.580 & 9.359 & 0.000 & Significant \\
Innovativeness $\rightarrow$ Behavioral_Intention & 0.063 & 1.125 & 0.261 & Not Significant \\
Insecurity $\rightarrow$ Behavioral_Intention & 0.105 & 1.617 & 0.106 & Not Significant \\
ME_DIS $\rightarrow$ Behavioral_Intention & 0.150 & 1.796 & 0.073 & Not Significant \\
ME_INN $\rightarrow$ Behavioral_Intention & 0.024 & 0.330 & 0.741 & Not Significant \\
ME_INS $\rightarrow$ Behavioral_Intention & -0.022 & 0.288 & 0.773 & Not Significant \\
ME_OPT $\rightarrow$ Behavioral_Intention & -0.028 & 0.397 & 0.692 & Not Significant \\
Optimism $\rightarrow$ Behavioral_Intention & 0.163 & 2.862 & 0.004 & Significant \\
\hline
\end{tabular}


Variable discomfort and insecurity also do not have a significant effect on behavioral intention ( $\mathrm{H} 3$ and $\mathrm{H} 4$ rejected). This is because these two variables are inhibitor variables of technology readiness that show a person's negative side in using technology. This is also supported by research from Nugroho and Fajar (2017) which shows that the variables of discomfort and insecurity do not affect perceived ease of use and perceived usefulness, which are behavioral variables that form the technology acceptance model.

\section{Managerial Implications}

Consumers use online transportation through applications, therefor the high level of smartphone users in Indonesia and Thailand can also influence the results of hypotheses 3 and 4 . According to the results of a survey from Google and Temasek entitled 'e-Conomy SEA 2018', smartphone users in Indonesia reach 60 percent of the total population and Thailand with 70 percent of the total population. Thus, even though it was found that the level of discomfort and insecurity from Indonesian and Thai respondents are still high, this is not a major factor affecting their loyalty using online transportation. Therefore, based on this study it is found that both in Indonesia and Thailand, the level of discomfort and insecurity do not affect a person's behavioral intention to use online transportation.

Therefore, from this result, the companies of online transportation should make the right strategies, such as pricing and quality service. In Thailand, people tend to use public transportation such as buses, songtaew, MRT, BTS and others because the prices offered by online transportation tend to be more expensive (Taneerananon, 2016). Meanwhile, in Indonesia pricing strategy also important because the pricing on online transportation is determined solely by calculating the distance and also the road congestion (Wahyuningtyas, 2016). Companies also should improve their quality service, because according to Damaini et al. (2018) there are a number of problems that occur quite frequently in online transportation and make it difficult for passangers and drivers, namely, troubled GPS network, bad ratings and comments given by passangers after using services, cancellation of orders resulting in financial loss, buy and sell driver account and fraud both from the driver and the passenger.

\section{CONCLUSIONS AND RECOMMENDATIONS}

\section{Conclusions}

Respondents in this study were dominated by female as much as 80 percent $(75.60$ percent in Indonesia and 84.40 percent in Thailand) with the majority of respondents in the age range of 16-25 years. This also caused the marriage status of the respondents to be dominated by singles. According to the average total income, the majority of respondents had income in the range of Rp1,000,001 to Rp2,500,000 for Indonesia and less than 10,000 Baht ( $<$ Rp4,500, 000) for Thailand. Meanwhile, for the average total expenditure, it is dominated by a range of $\mathrm{Rp} 500,001$ to $\mathrm{Rp} 250,000$ for Indonesia and 5,000- 10,000 Baht (Rp250,000 $\mathrm{Rp} 4,500,000)$ for Thailand.

The results of the hypothesis test for these two countries are also no different. In hypothesis testing in Indonesia and Thailand, it was found that there were only two accepted hypotheses, H1 which stated that optimism had an effect on behavioral intention and H5 which stated that favorableness had an effect on behavioral intention. However, favorableness as a moderating variable does not mediate the relationship between each independent variable to the dependent variable. From the results of this study, it can be concluded that there are similarities between the people of Indonesia and Thailand in their technological readiness and their behavioral intention to use online transportation. Therefore, online transportation companies can develop strategies that are not much different for these two countries.

\section{Recommendations}

Based on the results of this study, it is suggested that online transportation companies review the strategies that have been implemented so far, and focus on improving the quality of services to improve convenience for consumers in accessing services. In addition, pricing is important to be able to compete with other public transportation and conventional taxi. Furthermore, it is necessary to develop deeper and broader research such as making comparisons with other countries, especially those outside of Asia that have online transport policies or policies that are far different from Indonesia, so that online transportation companies in Indonesia can also learn from outside countries and can expand the market. In addition, 
further research can examine other objects that are still related to technology, such as Airbnb, Amazon.com, eBay and others.

\section{REFERENCES}

Abdillah W, Jogiyanto H. 2015. Partial Least Square (PLS Alternatif Structural Equation Modelling (SEM) dalam Penelitian Bisnis. Yogyakarta: Andi Offset

Ackaradejruangsri P. 2015. Insights on GrabTaxi: an alternative ride service in Thailand. Review Integrative Business \& Economics Research 4(3):49-61.

Aziah A, Adawia P. 2018. Analisis perkembangan industri transportasi online di era inovasi disruptif (Studi Kasus PT Gojek Indonesia). Jurnal Humaniora Bina Sarana Informatika 18(2):149-156.

Damaini A, Suyoto S, Nugroho G. 2018. Fraud crime mitigation of mobile application users for online transportation. International Journal of Interactive Mobile Technologies 12(3):153-167

Ghozali I. 2014. Structural Equation Modeling Metode Alternatif Dengan Partial Least Squares (PLS). Semarang: Badan Penerbit Undip.

Indrayana B, Seminar KB, Sartono B. 2016. Faktor penentu minat penggunaan instagram untuk pembelian online menggunakan Technology Acceptance Model (TAM) dan Theory of Planned Behavior (TPB). Jurnal Aplikasi Bisinis dan Manajemen 2(2):138-147.

Lin J, Lin C, Hsieh P. 2006. The role of technology readiness in customers perception and adoption of self-service technologies. International Journal of Service Industry Management 7(5):497-517.

Lin J, Hsieh P. 2007. The influence of technology readiness on satisfaction and behavioral intentions toward self-service technologies. Computers in Human Behavior 23:1597-1615.

Moroni I, Arruda A, Araujo K. 2015. The design and technological innovation: how to understand the growth of startups companies in competitive business environment. Procedia Manufacturing 3:2199-2204.

Nugroho M, Fajar M. 2017. Effects of technology readiness towards acceptance of mandatory webbased attendance system. 4th Informaton Systems International Conference 2017. 124:319-328.
Nurhidayah F, Alkarim F. 2017. Domination of Transportation Network Companies (TNCs) in Indonesia: An Indonesian case. International Journal of Business, Economics and Law 12(3):11-20.

Parasuraman A. 2000. Technology Readiness Index (TRI): a multiple-iteem scale to measure readiness to embrace new technologies. Journal of Service Research 2(4):307-320.

Parasuraman A, Colby C. 2014. An Uptaded and Streamlined Technology Readiness Index: TRI 2.0. Journal of Service Research Pg 1-16. https:// doi: 10.1177/1094670514539730.

Santoso A, Nelloh L. 2017. User satisfaction and intention to use peer-to-peeronline transportation: a replication study. Procedia Computer Science 124: 379-387.

Sarwono J. 2013. Statistik Multivariat Aplikasi untuk Riset Skripsi. Yogyakarta: Andi Offset.

Septiani R, Handayani P, Azzahro F. 2017. Factors that affecting behavioral intention in online transportation service: case study of Go-Jek. Procedia Computer Science 134:504-512.

Silalahi S, Handyani P, Munajat Q. 2017. Service quality analysis for online transportation services: case study of Go-Jek. Procedia Computer Science 124:487-495.

Son M, Han K. 2011. Beyond the technology adoption: technology readiness effects on post-adoption behavior. Journal of Business Research 64:1178 1182. https://doi:10.1016/j.jbusres.2011.06.019.

Speranza M. 2018. Trends in transportation an d logistics. European Journal of Operational Research 264: 830-836. http://dx.doi. org/10.1016/j.ejor.2016.08.032.

Taneerananon S. 2012. Getting out of the rut of poverty in Thailand: through transport accessibility. Journal of Society for Transportation and Traffic Studies 7(4):30-36.

Wahyuningtyas S. 2016. The Online Transportation Network in Indonesia: A Pendulum Between The Sharing Economy and Ex Ante Regulation. Competition and Regulation in Network Industries. Pg 260-280. https://doi.org/10.1177 $\% 2 F 178359171601700304$.

Zeithaml V, Berry L, Parasuraman A. 1996. The behavioral consequences of service quality. Journal of Marketing 60(2):31-46. 